\title{
A Phage for Generalized Transduction in Bacillus thuringiensis and Mapping of Four Genes for Antibiotic Resistance
}

\author{
By RITVA LANDÉN, AgNETA HEIERSON AND HANS G. BOMAN* \\ Department of Microbiology, University of Stockholm, S-106 91 Stockholm, Sweden
}

(Received 17 June 1980)

\begin{abstract}
A phage $(\phi 63)$ for generalized transduction in Bacillus thuringiensis was isolated from a soil sample. The diameter of the head was $95 \mathrm{~nm}$ and the tail length was $200 \mathrm{~nm}$. The growth cycle required $75 \mathrm{~min}$ and the burst size was 330 . Phage $\phi 63$ was stabilized by $\mathrm{Ca}^{2+}$ ions and phage stocks could be stored cold without loss of titre. The frequency of transduction of $\mathrm{Leu}^{+}$ into an auxotrophic strain was $2 \times 10^{-6}$. The frequency of transduction of genes for resistance to nalidixic acid, rifampicin, streptomycin and spectinomycin was generally an order of magnitude lower. Phage $\phi 63$ could cotransduce these four genes for antibiotic resistance. Crosses were performed which established the gene order as nalA-rifA$\operatorname{str} A-\operatorname{spc} A$. Heterologous cotransduction of rifA and $\operatorname{str} A$ at reasonable frequencies was obtained in three of six subspecies.
\end{abstract}

\section{INTRODUCTION}

A number of insect pathogens have been used for biological control of pests (Briggs, 1977; Bulla et al., 1975). The most useful of these organisms is Bacillus thuringiensis, which produces an infective spore and a crystalline protein toxin. Bacillus thuringiensis is known to produce five or six different toxins (Faust, 1977) and also specific inhibitors of the immune system of insects (Edlund et al., 1976; Sidén et al., 1979). About 20 subspecies of $B$. thuringiensis are recognized (Bulla et al., 1975; Ren et al., 1975; Tyrell et al., 1979) and some of them differ in their pathogenicity to various insects. Systems for genetic exchange in $B$. thuringiensis could be of potential use for the construction of tailor-made insect pathogens.

Several phages of $B$. thuringiensis have been described, chiefly emphasizing morphology, physiological properties, host resistance or phage typing (Bogush et al., 1977; Chapman \& Norris, 1966: Colasito \& Rogoff, 1969a, b; Sha et al., 1975; Van Tassel \& Yousten, 1976). More recently, Thorne described two $B$. cereus phages that could perform generalized transduction in B. thuringiensis (Thorne, 1978). However, both phages were reported to be cold sensitive (Thorne, 1978; Van Tassel \& Yousten, 1976) and in our hands the better one, CP-54, proved difficult to handle. This prompted us to isolate a set of phages from soil. We now report that one of these phages, $\phi 63$, can perform generalized transduction in $B$. thuringiensis. We have used this phage to determine the map order of four antibiotic resistance genes of which three are part of a ribosomal cluster. We also demonstrate that phage $\phi 63$ mediates heterologous cotransduction in five of the six subspecies of $B$. thuringiensis tested.

\section{METHODS}

Bacterial strains and isolation of mutants. The strains of Bacillus thuringiensis used and their sources are given in Table 1. Strains Bt 2 and Bt 3 were isolated as clones from samples of the commercial insecticides Biotrol XK (Nutrilite Products, Lakeview, Calif. 92664, U.S.A.) and Entobacterin 3 (Moscow, U.S.S.R.). Strain Bt4 was isolated in the same way from a commercial powder of the international reference strain E61, originating from 
Table 1. Bacillus thuringiensis strains used

\begin{tabular}{|c|c|c|c|c|c|c|c|c|c|c|}
\hline \multirow[b]{2}{*}{ Strain } & \multirow[b]{2}{*}{ Parent } & \multirow[b]{2}{*}{$\begin{array}{l}\text { B. thuringiensis } \\
\text { subspecies }\end{array}$} & \multicolumn{4}{|c|}{ Genotype (alleles) } & \multicolumn{3}{|c|}{ Other properties* } & \multirow[b]{2}{*}{ Source/reference ${ }^{\dagger}$} \\
\hline & & & nal & rif & str & $s p c$ & Exo & Cry & Spo & \\
\hline Bt 1 & - & gelechiae $\ddagger$ & + & + & + & + & + & - & + & Sebesta \& Horska (1970) \\
\hline Bt 11 & $\mathrm{Bt} l$ & gelechiae & + & + & $A I$ & + & + & - & + & Edlund et al. (1976) \\
\hline Bt 12 & $\mathrm{Bt} 11$ & gelechiae & + & $A l$ & $A 1$ & + & + & - & + & Edlund et al. (1976) \\
\hline Bt 13 & $\mathrm{Bt} 1$ & gelechiae & $A I$ & + & + & + & + & - & + & Sp, this paper \\
\hline Bt 14 & $\mathrm{Bt} 1$ & gelechiae & + & $A 3$ & + & + & + & - & & $\mathrm{Sp}$, this paper \\
\hline Bt 101 & Bt l & gelechiae & + & + & + & $A 2$ & + & - & + & $\mathrm{Sp}$, this paper \\
\hline Bt 103 & Bt 101 & gelechiae & + & $A 2$ & + & $A 2$ & + & - & & Sp, this paper \\
\hline Bt 131 & Bt 13 & gelechiae & $A 1$ & + & $A 2$ & + & + & - & + & $\mathrm{Sp}$, this paper \\
\hline Bt 1101 & Bt 11 & gelechiae & + & + & $A I$ & $A 3$ & + & - & + & Sp, this paper \\
\hline Bt 1134 & Bt 12 & gelechiae & + & $A 1$ & $A I$ & + & - & - & - & NG, T. Edlund (unpublished) \\
\hline Bt 1140 & $\mathrm{Bt} 1134$ & gelechiae & + & $A l$ & $A 1$ & $A 1$ & - & - & - & Sp, this paper \\
\hline Bt 1314 & Bt131 & gelechiae & $A 1$ & $A 4$ & $A 2$ & + & + & - & & Sp, this paper \\
\hline $\mathrm{Bt} 2$ & - & kurstaki & + & + & + & + & - & + & + & Biotrol XK \\
\hline Bt3 & - & galleriae & + & + & + & + & - & + & + & Entobacterin 3 \\
\hline $\mathrm{Bt} 4$ & - & thuringiensis & + & + & + & + & + & + & + & E61 \\
\hline $\mathrm{Bt} 5 \mathrm{w}$ & - & alesti & + & + & + & + & - & + & + & H. J. Somerville, 1979 \\
\hline Bt5 & $\mathrm{Bt} 5 \mathrm{w}$ & alesti & + & + & $r \S$ & + & - & + & + & H. J. Somerville, 1975 \\
\hline Bt 8 & - & finitimus & + & + & + & + & & & & H. J. Somerville, 1975 \\
\hline Btal & - & israelensis & + & + & + & + & & & & $\begin{array}{l}\text { H. de Barjac, } 1977 ; \\
\text { identical to } 1897-10\end{array}$ \\
\hline Bta3 & - & ostrinae & + & + & + & + & & & & Ren et al. (1975) \\
\hline Bta40 & - & thompsoni & + & + & + & + & & & & $\begin{array}{l}\text { Thorne (1978); identical to } \\
\text { NRRL4060 }\end{array}$ \\
\hline Bta43 & $\mathrm{Bta} 40$ & thompsoni & + & + & + & + & & & & $\begin{array}{l}\text { Thorne (1978); } \text { Leu }^{-} \\
\text {identical to NRRL4060 } \\
\text { M52 }\end{array}$ \\
\hline Bta4301 & Bta43 & thompsoni & + & + & + & $\mathrm{r} \S$ & & & & $\mathrm{Sp}, \mathrm{Leu}^{-}$as in Bta43 \\
\hline HD 131 & - & aizawai & + & + & + & + & & & & H. T. Dulmage, 1977 \\
\hline
\end{tabular}

* Exo, production of $\beta$-exotoxin; Cry, crystal formation; Spo, ability to sporulate.

† Sp, spontaneous mutants; NG, mutants obtained by $N$-methyl- $N^{\prime}$-nitro- $N$-nitrosoguanidine treatment. Where only a name and year are given, this indicates from whom and when the strains were received.

$\ddagger$ gelechiae is the designation used by Sebesta; the strain is not a generally recognized subspecies.

$\S \mathrm{r}$, resistance, without further determination of locus.

the Institut Pasteur, Parix XV, France. Other strains used were Bacillus cereus Bc1l. a Str mutant from ATCC 11778 and Bacillus subtilis 168 obtained from L. Rutberg. Spontaneous antibiotic-resistant mutants were isolated by spreading about $10^{9}$ bacteria from an overnight culture on plates containing the appropriate antibiotic: $100 \mu \mathrm{g}$ streptomycin $\mathrm{ml}^{-1}, 100 \mu \mathrm{g}$ spectinomycin $\mathrm{ml}^{-1}, 25 \mu \mathrm{g}$ nalidixic acid ml $\mathrm{m}^{-1}$ and $5 \mu \mathrm{g}$ rifampicin $\mathrm{ml}^{-1}$.

Growth conditions and media. All bacteria used were grown at $37{ }^{\circ} \mathrm{C}$ and liquid cultures were incubated on rotary shakers. Minimal medium (MIN3) and phage assay medium (PA) were prepared as described by Thorne (1978). MIN4 medium was MIN3 supplemented with lysine, methionine and aspartic acid, each at $10 \mu \mathrm{g} \mathrm{ml}^{-1}$. Solid medium (LAG) was LB medium (Bertani, 1951) supplemented with $0.2 \%(\mathrm{w} / \mathrm{v})$ glucose and, when appropriate, antibiotics, and solidified with $1 \%(\mathrm{w} / \mathrm{v})$ agar. Liquid medium (LEG) was LB medium supplemented with mineral medium E (Vogel \& Bonner, 1956) and $0.2 \%(\mathrm{w} / \mathrm{v})$ glucose. All dilutions were performed with dilute nutrient broth $(0.1 \%, \mathrm{w} / \mathrm{v})$ containing $\mathrm{NaCl}(0.5 \%, \mathrm{w} / \mathrm{v})$. For transduction of auxotrophic markers, the soft agar contained only $0.6 \%(w / v)$ agar.

Isolation of phage $\phi 63$. Three different soil samples were used for enrichment cultures with LEG medium and strain Bt1134. Five different phages were isolated by single plaque purification. Preliminary experiments showed that two phages, $\phi 42$ and $\phi 63$, could perform generalized transduction. However, $\phi 63$ gave higher transduction frequencies and was selected for further study.

Preparation of phage stocks and assay methods. Phage stocks for transductions were prepared as follows. LAG plates were seeded with about $10^{7}$ plaque-forming units (p.f.u.) of $\phi 63$ and about $10^{7}$ colony-forming units (c.f.u.) from cultures of late-exponential phase bacteria. Plates were incubated at $37^{\circ} \mathrm{C}$ overnight and then overlaid with $3 \mathrm{ml}$ of dilution medium. After standing at room temperature for $4 \mathrm{~h}$, the phage suspension was recovered and centrifuged at $12000 \mathrm{~g}$ for $10 \mathrm{~min}$ at $4{ }^{\circ} \mathrm{C}$. Bacteria in the supernatant were killed by shaking with chloroform. 
The supernatant usually contained $10^{10}$ to $10^{11}$ p.f.u. $\mathrm{ml}^{-1}$. Phage were assayed by the soft agar overlay technique (Adams, 1959) with strain Btl as indicator on PA plates incubated at $37^{\circ} \mathrm{C}$ overnight. Phage stocks were regularly tested for bacterial sterility.

One-step growth curve. The one-step growth curve experiments were performed as described by Clowes \& Hayes (1968), except that cells were lysed with chloroform instead of streptomycin.

Phage antiserum. A $0.5 \mathrm{ml}$ portion of a crude phage stock (about $10^{10}$ p.f.u. $\mathrm{ml}^{-1}$ ) was injected intravenously into the ear of a rabbit. Injections were repeated after 2 and $10 \mathrm{~d}$, and the first serum was collected after 3 weeks. Later serum samples were taken 1 week after further boosters. The $K$ values of the antiserum varied from 200 to 500 when assayed by the method of Clowes \& Hayes (1968).

Transduction experiments. A $0.8 \mathrm{ml}$ portion of an overnight culture of the recipient bacteria was added to $40 \mathrm{ml}$ LEG medium. The bacteria were allowed to grow for $5 \mathrm{~h}$, then centrifuged and resuspended in 2 to $4 \mathrm{ml}$ LEG medium containing $2 \mathrm{mM}-\mathrm{CaCl}_{2}$ to give a final concentration of $2 \times 10^{9} \mathrm{c}$.f.u. $\mathrm{ml}^{-1}$. Samples of this bacterial suspension and phage $\phi 63$ (inactivated to 1 to $5 \%$ survival by u.v. irradiation) were mixed to give a multiplicity of infection (m.o.i.) of 1.5 and a final volume of $1 \mathrm{ml}$ (m.o.i. was calculated on p.f.u. before u.v. irradiation). Such transduction mixtures were incubated with gentle shaking for $30 \mathrm{~min}$ at $37^{\circ} \mathrm{C}$. After incubation the bacteria were washed with $10 \mathrm{ml}$ medium - MIN3, if the experiment concerned auxotrophic markers, otherwise LEG. The bacteria were resuspended in $1 \mathrm{ml}$ medium, an equal volume of undiluted phage antiserum was added, and the mixture was incubated for $10 \mathrm{~min}$ at $37^{\circ} \mathrm{C}$.

In experiments with the leucine marker, all bacteria were then spread directly on MIN4 plates using $0.2 \mathrm{ml}$ samples in soft agar. Experiments with antibiotic resistance genes required growth for phenotypic expression; this was achieved by diluting the suspension with $40 \mathrm{ml}$ LEG medium to a turbidity corresponding to less than $3 \times 10^{7}$ viable cells $\mathrm{ml}^{-1}$ and incubating at $37^{\circ} \mathrm{C}$. After $3 \mathrm{~h}$ growth, the bacteria were washed with $40 \mathrm{ml} \mathrm{LEG}$ medium, concentrated 40 -fold and incubated as before with $1 \mathrm{ml}$ of undiluted phage antiserum. Finally, $0.2 \mathrm{ml}$ samples were spread on the appropriate antibiotic plates. Transductants were scored on MIN4 plates after $48 \mathrm{~h}$, and on antibiotic plates after $36 \mathrm{~h}$. Control experiments were performed in the same way as the transductions, except that dilution medium was used instead of phage.

Antibiotic-resistant clones were transferred to master plates and tested without further purification for resistance to all relevant antibiotics.

Electron microscopy. A high-titre phage stock was dialysed for $48 \mathrm{~h}$ against $0.01 \mathrm{~m}$-potassium phosphate buffer. $\mathrm{pH} 6.4$, containing $0.15 \mathrm{M}-\mathrm{NaCl}$. One drop of phage suspension was put on a 300 mesh parlodion-coated copper grid and negatively stained with a fresh solution of 0.5 or $1 \%(\mathrm{w} / \mathrm{v})$ ammonium molybdate, $\mathrm{pH}$. The specimens were examined in a Jeol $100 \mathrm{~S}$ electron microscope.

Materials. Spectinomycin was kindly donated by Upjohn International, Kalamazoo, Mich. 49001, U.S.A. Other antibiotics were purchased from Sigma.

\section{RES ULTS}

\section{Characterization of phage $\phi 63$}

To be of maximum usefulness, a $B$. thuringiensis transducing phage should have a wide host range. We therefore examined phage $\phi 63$ for its ability to form plaques on 10 different subspecies of $B$. thuringiensis as well as strains of $B$. cereus and $B$. subtilis. The phage grew well on 8 of the 13 strains tested (Table 2). There was a modest restriction on subspecies finitimus and no growth at all on subspecies israelensis, aizawai and on one the derivatives of alesti. There was good growth on $B$. cereus and no growth on $B$. subtilis. Three strains which gave no plaques - Bta1, HD131 and B. subtilis 168 - were compared with Bt1 for phage adsorption. Equal evidence for receptors was found in Bt1, Btal and HD131 while no adsorption was demonstrated with $B$. subtilis.

The size of the phage was estimated from electron micrographs (Fig. 1): the diameter of the head was $95 \mathrm{~nm}$ and the tail length was $200 \mathrm{~nm}$. The one-step growth curve showed that $\phi 63$ had a latent period of $55 \mathrm{~min}$, a rise period of $20 \mathrm{~min}$ and a burst size of 330 (average data from three experiments). The phage was stable for many days when kept cold in the presence of $\mathrm{CaCl}_{2}$, but was destabilized by EDTA (Fig. 2).

\section{Strategy of the genetic work}

It is considerably easier to isolate antibiotic-resistant mutants than it is to obtain auxotrophs. Moreover, spontaneous mutations will often give isogenic strains, whereas 
Table 2. Plaque-forming ability of phage $\phi 63$ on different strains of Bacillus

\begin{tabular}{|c|c|c|c|}
\hline Strain & $\begin{array}{l}\text { B. thuringiensis } \\
\text { subspecies }\end{array}$ & $\begin{array}{c}\text { Plaque } \\
\text { morphology }\end{array}$ & E.o.p.* \\
\hline $\mathrm{Bt} 1$ & gelechiae & Clear & 1 \\
\hline $\mathrm{Bt} 2$ & kurstaki & Turbid & 0.4 \\
\hline Bt 3 & galleriae & Turbid & 0.5 \\
\hline $\mathrm{Bt} 4$ & thuringiensis & Turbid & 0.4 \\
\hline $\mathrm{Bt} 5 \mathrm{w}$ & alesti & Clear & $<10^{-9}$ \\
\hline $\mathrm{Bt} 5$ & alesti & Clear & 0.6 \\
\hline $\mathrm{Bt} 8$ & finitimus & Turbid & $10^{-3}$ \\
\hline Btal & israelensis & No plaques & $<10^{-8}$ \\
\hline Bta3 & ostrinae & Clear & 0.4 \\
\hline Bta40 & thompsoni & Turbid & 0.5 \\
\hline HD 131 & aizawai & No plaques & $<10^{-9}$ \\
\hline $\begin{array}{l}\text { B. cereus } \mathrm{Bc} 11 \\
\text { B. subtilis } 168\end{array}$ & & $\begin{array}{l}\text { Clear } \\
\text { No plaques }\end{array}$ & $\begin{array}{r}0.6 \\
<10^{-7}\end{array}$ \\
\hline
\end{tabular}

* Efficiency of plating of a stock of phage $\phi 63$, which was propagated on strain $\mathrm{Bt} 1$.
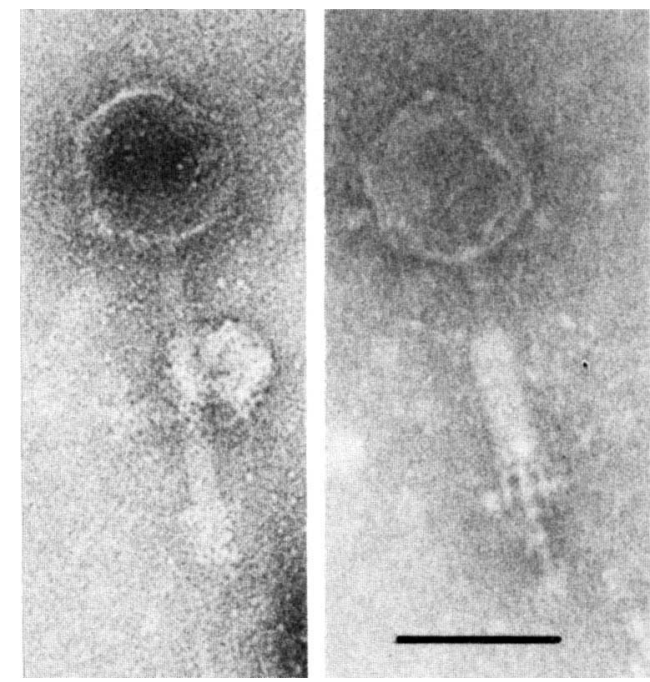

Fig. 1. Electron micrographs of phage $\phi 63$, negatively stained with $0.5 \%$ ammonium molybdate ( $\mathrm{pH} 7$ ): left, sheath extended: right, sheath contracted. The bar marker represents $0.1 \mu \mathrm{m}$.

mutagen treatments always give multiple mutations and sometimes chromosome alterations. Our first decision was, therefore, to use spontaneous antibiotic-resistant mutants for the development of a transduction system in Bacillus thuringiensis. During the isolation of streptomycin-resistant mutants, we found that the spontaneous mutation frequency was as high as $10^{-7}$ to $10^{-8}$. Such a high frequency made it difficult to distinguish between a low order of transduction and mutation. However, the expected frequency of double mutations would be $10^{-14}$ or lower while the frequency of cotransduction would remain around $10^{-7}$ to $10^{-8}$. Our second decision was, therefore, to screen directly for cotransduction because this would theoretically eliminate the possibility that a cotransduction was confused with a double mutation. In addition, such an approach might lead directly to a phage useful in further genetic work.

In Escherichia coli, resistance to streptomycin and spectinomycin are known to be 


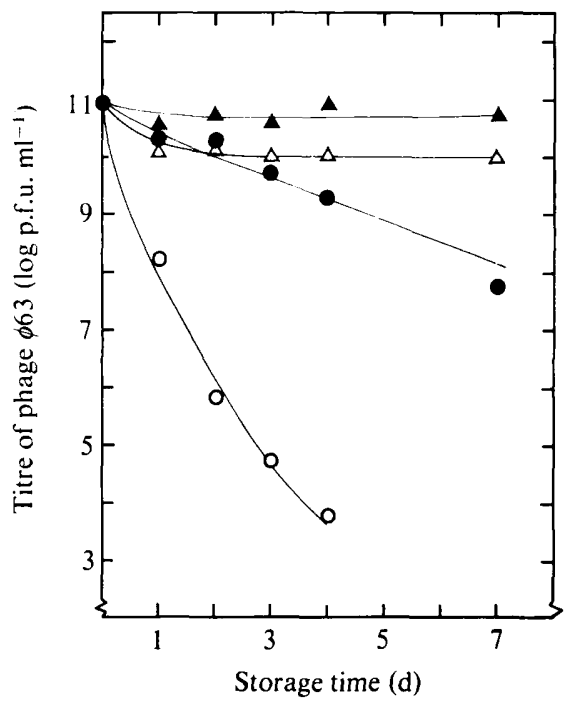

Fig. 2. Stability of phage $\phi 63$ at different temperatures. A high-titre phage stock containing $2 \mathrm{mM}-\mathrm{CaCl}_{2}$ was propagated on strain $\mathrm{Btl}$ as described in Methods. The stock was divided into four parts: two portions were stored at $37^{\circ} \mathrm{C}$, one with 4 mM-EDTA (O) and one without EDTA (O); the other two portions were stored at $4{ }^{\circ} \mathrm{C}$, one with 4 mM-EDTA $(\triangle)$ and one without EDTA $(\Delta)$. At intervals, samples were withdrawn and assayed for phage titre.

Table 3. Phage $\phi 63-m e d i a t e d$ transduction using single and double selection

\begin{tabular}{lclc}
\multicolumn{1}{c}{ Donor } & Recipient & Selection & No. of colonies* \\
Bt 1140 & Bt1 & $\operatorname{Str}^{r} \mathrm{Spc}^{\mathrm{r}}$ & 164 \\
Control without phage & $\mathrm{Bt} 1$ & $\mathrm{Str}^{\mathrm{r}} \mathrm{Spc}^{\mathrm{r}}$ & 0 \\
Bt 131 & $\mathrm{Bt} 1$ & $\mathrm{Str}^{\mathrm{r}}$ & 443 \\
Control without phage & $\mathrm{Bt} 1$ & $\mathrm{Str}^{\mathrm{r}}$ & 214
\end{tabular}

* Before plating the number of colony-forming units was $6 \times 10^{9} \mathrm{ml}^{-1}$. The multiplicity of infection was 0.9 in the first experiment with double selection, and 1.7 in the second.

alterations in ribosomal proteins P10 and P4 of the 30 S subunit (Taylor \& Trotter, 1972). Since ribosomal genes are known to be clustered (Hoch, 1978; Taylor \& Trotter, 1972; Young \& Wilson, 1975), we screened our phages for their ability to cotransduce $\operatorname{Str}^{r}$ and $\mathrm{Spc}^{r}$. For comparison we also included an experiment with selection for only one of the markers used. From the results in Table 3 we conclude that phage $\phi 63$ can perform cotransduction and that the phage would be potentially useful for the development of the genetics of $B$. thuringiensis.

\section{Optimizing the conditions for transduction with phage $\phi 63$}

Using a leucine auxotroph we investigated some parameters found to influence the overall yield of transductants. Table 4 shows that an important step was the u.v. inactivation of the phage. In this experiment the reversion rate of the marker was low as indicated from the two controls. Before plating, antiserum was added to all of the samples in Table 4 (see Methods). If antiserum against $\phi 63$ was omitted the number of colonies obtained was of the same order but the colony morphology indicated heavy lysis. Such transductants could be tested for cotransduction only with great difficulty. Thus, it is important to prevent phage multiplication after the first infection. 
Table 4. Parameters affecting the transduction frequency with phage $\phi 63$ carrying Leu $^{+}$ from strain Bta40

Transduction conditions*

\begin{tabular}{lcc}
\multicolumn{1}{c}{ Addition } & $\begin{array}{c}\text { No. of } \mathrm{Leu}^{+} \\
\text {colonies }\end{array}$ \\
None & 98 & $3791 \ddagger$ \\
None & 0 & 1179 \\
4 mM-EDTA & 98 & 607 \\
Preincubation with antiserum ${ }^{+}$ & 98 & 28 \\
Control without phage & 0 & 16
\end{tabular}

* The multiplicity of infection in all experiments was $1 \cdot 25$. All samples contained $2 \mathrm{mM}-\mathrm{CaCl}_{2}$. The recipient was strain Bta4301.

$\dagger$ Antiserum against $\phi 63$ was added before the phage were allowed to adsorb to the recipient strain.

$\ddagger$ This number corresponds to a transduction frequency of $2 \times 10^{-6}$ per p.f.u.

Table 5. Phage $\phi 63-m e d i a t e d$ cotransduction between strAl and two other genes in the ribosomal cluster

\begin{tabular}{|c|c|c|c|c|c|c|}
\hline \multirow[b]{2}{*}{ Donor } & \multirow[b]{2}{*}{ Recipient } & \multicolumn{2}{|c|}{ No. of $\mathrm{Str}^{\mathrm{r}}$ colonies } & \multicolumn{3}{|c|}{$\begin{array}{c}\text { Cotransduction of unselected } \\
\text { markers }(\%) \dagger\end{array}$} \\
\hline & & Obtained* & Tested & rifAl & $\operatorname{spcA^{+}}$ & rifAl $s p c A^{+}$ \\
\hline \multicolumn{7}{|l|}{ Cross A } \\
\hline $\begin{array}{l}\mathrm{Bt} 1134 \\
\quad(\text { rifAl strAl spcA }\end{array}$ & $\begin{array}{l}\mathrm{Bt} 101 \\
\quad\left(\text { rifA } A^{+} \operatorname{str} A^{+} \operatorname{spcA2}\right)\end{array}$ & 651 & 502 & 17 & 8 & 54 \\
\hline Control without phage & $\begin{array}{l}\mathrm{Bt} 101 \\
\quad\left(\text { rif } A^{+} \operatorname{str} A^{+} \operatorname{spc} A 2\right)\end{array}$ & 64 & 18 & 0 & 0 & 0 \\
\hline Cross B & & & & rifAl & $\operatorname{spcAl}$ & rifAI spcAl \\
\hline $\begin{array}{l}\mathrm{Bt} 1140 \\
\quad(\text { rifAl strAl spcAl) }\end{array}$ & $\begin{array}{l}\mathrm{Bt} 1 \\
\quad(\text { rifA } \\
+\end{array}$ & 497 & 355 & 28 & 13 & 50 \\
\hline Control without phage & 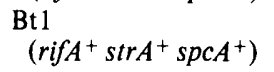 & 40 & 32 & 0 & 0 & 0 \\
\hline
\end{tabular}

* When the number of spontaneous mutants was subtracted from the number of colonies obtained with $\phi 63$, the calculated transduction frequency was $4 \times 10^{-7}$ for cross $\mathrm{A}$ and $2 \times 10^{-7}$ for cross $\mathrm{B}$.

+ Not shown are the transductants which received only the strAI marker. For cross A this number (40) was calculated as the difference between the number of colonies which were only $\operatorname{Str}^{r}$ and $s p c A 2(104)$ and the number of spontaneous $\mathrm{Str}^{\mathrm{r}}$ colonies (64). This recombinant class is of the same order as the one which received $s p c A^{+}$together with $\operatorname{sir} A l$.

Table 6. Three-factor crosses with selection for crossover between rifA and strA

\begin{tabular}{|c|c|c|c|c|c|c|}
\hline \multirow[b]{2}{*}{ Donor } & \multirow[b]{2}{*}{ Recipient } & \multirow{2}{*}{$\begin{array}{l}\text { Donor } \\
\text { marker } \\
\text { selected }\end{array}$} & \multicolumn{2}{|c|}{ 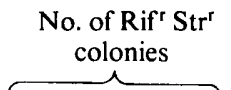 } & \multicolumn{2}{|c|}{$\begin{array}{l}\text { Colonies with } \\
\text { rifA strA spcA }\end{array}$} \\
\hline & & & Obtained & Tested & No. & $\% *$ \\
\hline \multicolumn{7}{|l|}{ Cross C } \\
\hline Bt $103\left(\right.$ rifA2 strA $\left.{ }^{+} s p c A 2\right)$ & $\mathrm{Bt} 11\left(\right.$ rif $\left.A^{+} \operatorname{str} A 1 \operatorname{spc} A^{+}\right)$ & rifa2 & 810 & 676 & 10 & 8 \\
\hline Control without phage & Bt $11\left(\right.$ riff $\left.A^{+} \operatorname{str} A 1 s p c A^{+}\right)$ & $\ldots$ & 689 & 460 & 0 & 0 \\
\hline \multicolumn{7}{|l|}{ Cross D } \\
\hline $\mathrm{Bt} 1101\left(\right.$ rif $\left.A^{+} \operatorname{strA} 1 \operatorname{spc} A 3\right)$ & Bt 14 (rifA3 strA $\left.A^{+} s p c A^{+}\right)$ & strAl & 125 & 124 & 26 & 66 \\
\hline Control without phage & $\mathrm{Bt} 14\left(\right.$ rif $\left.A 3 \operatorname{str} A^{+} s p c A^{+}\right)$ & - & 86 & 76 & 0 & 0 \\
\hline
\end{tabular}

Cross C

* The total number of rifA strA transductants was calculated by subtracting the number of spontaneous mutants obtained in the controls. This number was used to calculate the percentage of rifA strA spcA recombinants. 


\section{Mapping of genes rif $A$, strA and spcA in the ribosomal cluster}

To determine the order of these genes we performed a number of transduction experiments. Table 5 shows two crosses with primary selection for only strA. The genotype of the donor and the recipient were chosen so that the transductants could be tested for the cotransfer of rifA 1 and of $s p c A 1$ or their wild-type alleles. The results in Table 5 show that three genes were cotransduced at a higher frequency than two, indicating a close linkage of all three genes. Moreover, rifA was cotransduced at a frequency higher than observed for $s p c A^{+}$. If the gene order had been $r i f-s p c-s t r$ such a result would have required a double crossover for the rifAI recombinants. This gene order can thus be excluded and we conclude that $s p c$ is not located in the centre of the cluster.

To determine that the str gene was located between rif and $s p c$ we performed two inverted-marker crosses with rifA and $\operatorname{str} A$ in different strains and selected for crossover between these genes (Table 6). We then compared the frequency of transductants which were resistant to all three antibiotics. The results in Table 6 show that cross $\mathrm{C}$ gave only $8 \%$ of recombinants with this phenotype, while in cross $D$ the frequency was $66 \%$, numbers indicating a double crossover in cross $\mathrm{C}$ and a single crossover in cross $\mathrm{D}$. Since $s p c$ must be in a distal position (see Table 5) the results in Table 6 are only compatible with the gene order rifA-strA-spcA.

\section{Cotransduction between nalA and the ribosomal cluster}

Two crosses were performed to demonstrate that nalA and strA were cotransducible. Table 7 shows that with double selection for $\operatorname{Rif}^{\mathrm{r}}$ and $\operatorname{Str}^{\mathrm{r}}$ it was possible to demonstrate a low frequency of cotransduction between nalA and $s p c A$. Since only $5 \%$ of the transductants were nalAl while $69 \%$ were $s p c A^{+}$, nalA1 must be outside the region rifA-strA-spcA. In a similar cross with double selection for $\mathrm{Nal}^{\mathrm{r}}$ and $\mathrm{Str}^{\mathrm{r}}, 52 \%$ of all clones were found to carry all four donor markers (Table 7). Of the remaining clones $42 \%$ received rifA 4 but only $6 \%$ $s p c A^{+}$. These results indicate that nalA is on the rif side of the rif-spc cluster.

\section{Heterologous transduction of ribosomal genes mediated by phage $\phi 63$}

As demonstrated in Table 3, double selection eliminated the background of spontaneous mutations and it was therefore the method of choice for the investigation of heterologous transduction, a phenomenon which would be expected to be rare. Table 8 shows that rifA1 and strAl from subspecies gelechiae could be cotransduced with a reasonable frequency to three other subspecies and with a reduced frequency to an additional two subspecies. No transfer of the ribosomal genes was obtained to subspecies ostrinae.

\section{DISCUSSION}

The spontaneous mutation frequency to antibiotic resistance. The mutation frequency to $\mathrm{Str}^{\mathrm{r}}$ was always one or two orders of magnitude higher than the reversion rate for the leucine auxotroph Bta43 (Tables 3 and 4). Moreover, the spontaneous mutation rate to Rif ${ }^{r}$ was one order of magnitude higher than the rate for $\operatorname{Str}^{\mathrm{r}}$ (Table 6). Whether these fluctuating frequencies can be traced to transposons or other unorthodox genetic events remains to be determined.

Phage $\phi 63$ as a transducing vector. As preincubation of phage $\phi 63$ with antiserum reduced the number of $\mathrm{Leu}^{+}$colonies to less than $1 \%$, the genetic events recorded in Table 4 must be mediated by $\phi 63$. Altogether (Tables 4 and 7) five different genes were transferred. Moreover, when transductants with 17 different genotypes were investigated for sensitivity to reinfection with $\phi 63$, no case of immunity was detected (results not shown). Thus, $\phi 63$ must be a phage for generalized transduction of auxotrophic markers and antibiotic resistance genes. We have so far no evidence for a helper phage or for conversion (Perlak et al., 1979) but we intend to study the mechanism of $\phi 63$ transduction further. 


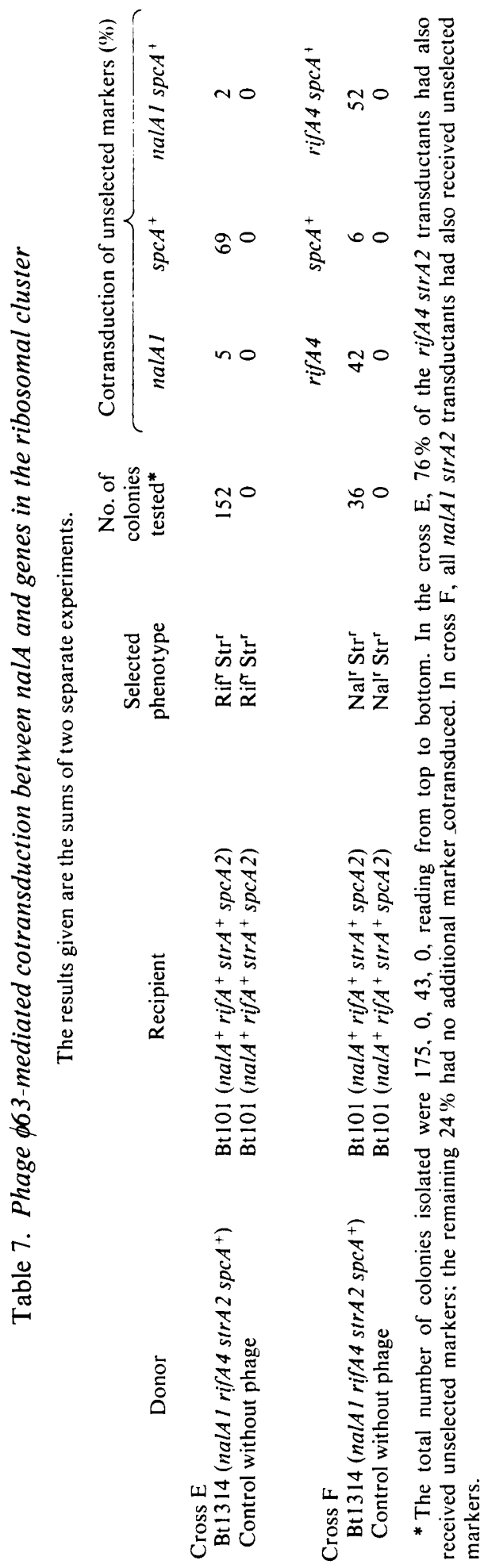


Table 8. Phage ф63-mediated heterologous cotransduction of rifA1 strA1

The stock of $\phi 63$ used was propagated on strain Bt1134. The data shown are from two separate experiments. The number of colonies isolated with $\mathrm{Bt} 1$ as recipient varied between 414 and 1722 .

$\begin{array}{clc}\text { Recipient } & \begin{array}{c}\text { B.thuringiensis } \\ \text { subspecies }\end{array} & \begin{array}{c}\text { Relative cotransduction } \\ \text { frequency (\%) }\end{array} \\ \mathrm{Bt} 1 & \text { gelechiae } & 100 \\ \mathrm{Bt} 2 & \text { kurstaki } & 10 \\ \mathrm{Bt} 3 & \text { galleriae } & 50 \\ \mathrm{Bt} 4 & \text { thuringiensis } & 80 \\ \mathrm{Bt} 8 & \text { finitimus } & 2 \\ \mathrm{Bta} 3 & \text { ostrinae } & <0.2 \\ \mathrm{Bta} 40 & \text { thompsoni } & 1\end{array}$

We have shown that the background of spontaneous mutations could be reduced to zero by selection for cotransduction (Tables 3 and 7). In Table 5 the background was around $10 \%$ while in Table 6 it was $85 \%$ and $69 \%$ in the two crosses. In the controls there was not a single clone which carried two of the markers involved. These results, together with those presented in Tables 3 and 7, show that cotransduction can be performed even against a high background level of spontaneous mutations.

In our laboratory we have compared phages CP-54 (Thorne, 1978) and $\phi 63$ and found the latter to be considerably more stable and easier to work with. Moreover, with $\phi 63$ we regularly obtained transduction frequencies for $\operatorname{Str}^{\mathrm{r}}$ around $5 \times 10^{-7}$ per p.f.u. compared with $3 \times 10^{-8}$ with phage CP-54. A paper describing phage TP-13, which mainly concerns conversion of sporulation and crystal formation in B. thuringiensis (Perlak et al., 1979), was published while this work was in preparation. Thus, at present we cannot compare the usefulness of phages $\phi 63$ and TP-13 for future genetic work. However, in no previous case has cotransduction of more than two genes been reported (Perlak et al., 1979; Thorne, 1978) compared with the four demonstrated here with $\phi 63$ (Table 7).

The transduction frequencies obtained for antibiotic resistance genes were always an order of magnitude lower than those found for auxotrophic markers (cf. Tables 4 and 5). One explanation could be that the phenotypic expression required for the ribosomal genes involves a disadvantage compared with when a gene for a missing enzyme converts an auxotroph to a prototroph. Whether this is a phenomenon related only to Bacillus thuringiensis or also to $\phi 63$ remains to be investigated.

The host range pattern of other $B$. thuringiensis phages described was investigated either by non-quantitative spotting of a concentrated phage suspension on a lawn of bacteria (Ackermann \& Smirnoff, 1978; Chapman \& Norris, 1966) or by cross-streaking (Perlak et al., 1979). We determined efficiencies of plating (Table 2), which showed that 8 of the 13 strains tested were sensitive to $\phi 63$. This broad host range pattern should contribute to the usefulness of the phage.

The map order of the antibiotic resistance markers. The order of genes indicated (Tables 5 , 6 and 7) was nalA-rifA-strA-spcA, which is the same as in B. subtilis (Hoch, 1978; Young $\&$ Wilson, 1975). Possible differences in the times needed for phenotypic expression can make our linkage data uncertain. However, the distance nalA-rifA is probably about three times longer than the distance $\operatorname{str} A-s p c A$. It should also be mentioned that we have failed to cotransduce leu with $s p c$, the only antibiotic resistance marker available to us in subspecies thomsoni.

Phage SP-10, which is of the same order of size as $\phi 63$, can cotransduce leul-argl (Tyeryar et al., 1969), a distance corresponding to 3 to $5 \%$ of the $B$. subtilis genome (Hoch, 1978; Young \& Wilson, 1975). In this organism the distance nal-spc is about $6 \%$ (Hoch, 1978; Young \& Wilson, 1975) but in B. thuringiensis it may be considerably shorter because the ribosomal RNA genes are lacking in spacer DNA (Klier et al., 1979). Thus, the 
cotransduction of $n a l A-s p c A$ reported here may well be compatible with the size of phage $\phi 63$.

Heterologous transduction in B. thuringiensis. Heterologous cotransduction was obtained at varying frequencies in five of the subspecies studied (Table 8). Temperate phages and plasmids have been reported in several subspecies of $B$. thuringiensis (Ackermann \& Smirnoff, 1978; Colasito \& Rogoff, $1969 \mathrm{~b}$; Faust et al., 1977; Stahly et al., 1978; Zakharyan et al., 1979) and some of them could be responsible for the restrictions demonstrated in Table 2. A further study of phage $\phi 63$ as well as characterization of the postulated restricting factors are probably needed in order to obtain a more efficient interstrain transduction system. However, the data presented show that phage $\phi 63$ is very useful for mapping studies in strain $\mathrm{Bt} 1$ and its derivatives.

This work was supported by grants from the Swedish Natural Science Research Council (B2453-100) and the Knut and Alice Wallenberg Foundation.

\section{REFEREN CES}

AckermanN, H.-W. \& Smirnoff, W. A. (1978). Recherches sur la lysogénie chez Bacillus thuringiensis et $B$. cereus. Canadian Journal of Microbiology 24, 818-826.

Adams, M. H. (1959). Bacteriophages. New York: Interscience.

Bertani, G. (1951). Studies of lysogenesis. I. The mode of phage liberation by lysogenic Escherichia coli. Journal of Bacteriology 62, 293-300.

Bogush, V. G., Smirnov, V. B., Rebentish, B. A., Permogorov, V. I. \& Azizbekyan, R. R. (1977). Physicochemical properties of some Bacillus thuringiensis phages. Molekulyarnaya Biologiya 11, 901-908.

BrIGGS, J. D. (editor) (1977). Biological Regulation of Vectors. The Saprophytic and Aerobic Bacteria and Fungi. Washington: DHEW Publication No. (NIH) $77-1180$.

Bulla, Jr, L. A., Rhodes, R. A. \& St Julian, G. (1975). Bacteria as insect pathogens. Annual Review of Microbiology 29, 163-190.

Chapman, H. M. \& Norris, J. R. (1966). Four new bacteriophages of Bacillus thuringiensis. Journal of Applied Bacteriology 29, 529-535.

Clowes, R. C. \& Hayes, W. (1968). Experiments in Microbial Genetics. Oxford: Blackwell Scientific Publications.

Colasito, D. J. \& Rogoff, M. H. (1969a). Characterization of lytic bacteriophages of Bacillus thuringiensis. Journal of General Virology 5, 267-274.

Colasito, D. J. \& Rogoff, M. H. (1969b). Characterization of temperate bacteriophages of Bacillus thuringiensis. Journal of General Virology 5, 275281.

Edlund, T., Sidén, I. \& Boman, H. G. (1976). Evidence for two immune inhibitors from Bacillus thuringiensis interfering with the humoral defense system of Saturniid pupae. Infection and Immunity 14, 934-941.

FaUST, R. M. (1977). Toxins of Bacillus thuringiensis: mode of action. In Biological Regulation of Vectors. The Saprophytic and Aerobic Bacteria and Fungi, pp. 31-48. Edited by J. D. Briggs. Washington: DHEW Publication No. (NIH), 77-1180.
Faust, R. M., Spizizen, J., Gage, V. \& Travers, R. S. (1979). Extrachromosomal DNA in Bacillus thuringiensis var. kurstaki, var. finitimus, var. sotto and in Bacillus popilliae. Journal of Invertebrate Pathology 33, 233-238.

Hосн, J. A. (1978). Developmental genetics at the beginning of a new era. In Spores VII, pp. 119121. Edited by G. Chambliss \& J. C. Vary. Washington, D.C.: American Society for Microbiology.

KLIER, A. F., KunSt, F. \& RAPOPORT, G. (1979). Structure of cloned ribosomal DNA cistrons from Bacillus thuringiensis. Nucleic Acids Research 7, 997-1010.

Perlak, F. J., Mendelsohn, C. L. \& Thorne, C. B. (1979). Converting bacteriophage for sporulation and crystal formation in Bacillus thuringiensis. Journal of Bacteriology 140, 699-706.

REN, G.-X., LI, K., YANG, M. \& YI, X. (1975). The classification of the strains of Bacillus thuringiensis group. Acta microbiologica sinica 15, 292-301 (in Chinese, with English summary).

Sebesta, K. \& Horska, K. (1970). Mechanism of inhibition of DNA-dependent RNA polymerase by exotoxin of Bacillus thuringiensis. Biochimica et biophysica acta 209, 357-376.

ShA, C.-Y., ReN, G.-X. \& XIE, O. J. (1975). Studies on phage-resistant strains of Bacillus thuringiensis var. galleriae "010" and the phages of Bacillus thuringiensis. Acta entomologica sinica 18, 273-280 (in Chinese, with English summary).

Sidén, I., Dalhammar, G., Telander, B., Boman, H. G. \& Sommerville, H. (1979). Virulence factors in Bacillus thuringiensis: purification and properties of a protein inhibitor of immunity in insects. Journal of General Microbiology 114, 45-52.

Stahly, D. P., Dingman, D. W., Bulla, JR, L. A. \& Aronson, A. I. (1978). Possible origin and function of the parasporal crystals in Bacillus thuringiensis. Biochemical and Biophysical Research Communications 84, 581-588.

TAYLOR, A. L. \& TROTTER, C. D. (1972). Linkage map of Escherichia coli strain K12. Bacteriological Reviews 36, 504-524. 
Thorne, C. B. (1978). Transduction in Bacillus thuringiensis. Applied and Environmental Microbiology 35, 1109-1115.

TYeRYAR, F. J., TAYLOR, M. J., LAwTON, W. D. \& GoldBerg, I. D. (1969). Cotransduction and cotransformation of genetic markers in Bacillus subtilis and Bacillus licheniformis. Journal of Bacteriology 100, 1027-1036.

Tyrell, D. J., Davidson, L. I., Bulla, JR, L. A. \& RamoskA, W. A. (1979). Toxicity of parasporal crystals of Bacillus thuringiensis subsp. israelensis to mosquitoes. Applied and Environmental Microbiology 38, 656-658.

Van TAssel, R. L. \& Yousten, A. A. (1976). Response of Bacillus thuringiensis to bacteriophage
CP-51. Canadian Journal of Microbiology 22 583-586.

Vogel, H. J. \& BonNeR, D. M. (1956). Acetylornithinase of Escherichia coli: partial purification and some properties. Journal of Biological Chemistry 218, 97-106.

Young, F. E. \& Wilson, G. A. (1975). Chromosomal map of Bacillus subtilis. In Spores VI, pp. 596-614. Edited by P. Gerhardt, R. N. Costilow \& H. L. Sadoff, Washington, D.C.: American Society for Microbiology.

Zakharyan, R. A., IsRaelyan, Yu. A., Agabalyan, A. S., Tatevosyan, P. E., Akopyan, S. M. \& Afrikyan, E. K. (1979). Plasmid DNA from Bacillus thuringiensis. Mikrobiologiya 48, 226-229. 